\title{
Civil protection and Damaging Hydrogeological Events: comparative analysis of the 2000 and 2015 events in Calabria (southern Italy)
}

\author{
Olga Petrucci $^{1}$, Tommaso Caloiero ${ }^{2}$, Angela Aurora Pasqua ${ }^{1}$, Piero Perrotta $^{3}$, Luigi Russo ${ }^{3}$, and Carlo Tansi ${ }^{3}$ \\ ${ }^{1}$ National Research Council of Italy, Research Institute for Geo-hydrological Protection (CNR-IRPI), \\ Rende (CS), 87036, Italy \\ ${ }^{2}$ National Research Council of Italy, Institute for Agriculture and Forest Systems in the Mediterranean (CNR-ISAFOM), \\ Rende (CS), 87036, Italy \\ ${ }^{3}$ Calabrian Civil Protection Unit, Catanzaro, 88100, Italy
}

Correspondence to: Tommaso Caloiero (tommaso.caloiero@isafom.cnr.it)

Received: 7 December 2016 - Revised: 11 September 2017 - Accepted: 9 October 2017 - Published: 9 November 2017

\begin{abstract}
Calabria (southern Italy) is a flood prone region, due to both its rough orography and fast hydrologic response of most watersheds. During the rainy season, intense rain affects the region, triggering floods and mass movements that cause economic damage and fatalities. This work presents a methodological approach to perform the comparative analysis of two events affecting the same area at a distance of 15 years, by collecting all the qualitative and quantitative features useful to describe both rain and damage. The aim is to understand if similar meteorological events affecting the same area can have different outcomes in terms of damage. The first event occurred between 8 and 10 September 2000, damaged 109 out of 409 municipalities of the region and killed 13 people in a campsite due to a flood. The second event, which occurred between 30 October and 1 November 2015, damaged 79 municipalities, and killed a man due to a flood. The comparative analysis highlights that, despite the exceptionality of triggering daily rain was higher in the 2015 event, the damage caused by the 2000 event to both infrastructures and belongings was higher, and it was strongly increased due to the 13 flood victims. We concluded that, in the 2015 event, the management of pre-event phases, with the issuing of meteorological alert, and the emergency management, with the preventive evacuation of people in hazardous situations due to landslides or floods, contributed to reduce the number of victims.
\end{abstract}

\section{Introduction}

Damaging Hydrogeological Events (DHE) occur due to a combination of predisposing factors, triggering causes and the presence of vulnerable elements (Petrucci and Polemio, 2009). A DHE is made of two components: a Rainfall Event (RE) and a subsequent Damage Event (DE), resulting from floods and landslides triggered by rain. Depending on both rivers and slopes conditions, the same rain amount either can or cannot cause damage. Moreover, damage occurrence depends on the geographical distribution of vulnerable elements such as population, lifelines and urbanized sectors. DHE can affect entire regions and may last for more than one day, and, accordingly, they can show high variability, both in space and in time. For this reason, it can be difficult to compare causes and effects of these events in a systematic way.

Over the last few years, in some countries, such as Italy, there has been an increase in both the recurrence and the severity of DHE's damage. Indeed, while during the past century the DHE were identified following the year of occurrence (e.g., the event of 1966), nowadays, the events are often identified by means of both the year and the month of occurrence, given that a region is frequently affected by more than one event per year. In several areas of the world, an increasing number of damaging events, related to increasing frequency and intensity of extreme precipitation have been highlighted (e.g. Alexander et al., 2006; Min et al., 2011; Westra et al., 2013). Climate models also indicate that further increases in extreme precipitation should be expected over 
the next decades (Pall et al., 2006; O'Gorman and Schneiderb, 2009; Toreti et al., 2013), with moist regions which are expected to be wetter, and dry regions drier (Chou and Neelin, 2004; Wentz et al., 2007; Zhang et al., 2007; Allan and Soden, 2008). In this framework, a great deal of research has been carried out on daily precipitation, by means of various methods of analysis, such as indices, percentiles, thresholds, and extreme value theory (Groisman et al., 2005; Reiser and Kutiel, 2010; Toreti et al., 2010; Durão et al., 2010; Caloiero et al., 2016). Several studies focused their attention on rain variability, evidencing positive trends in daily rain intensity and a tendency toward higher frequencies of heavy and extreme rainfall (Kunkel et al., 1999; Plummer et al., 1999; Osborn et al., 2002; Villarini et al., 2011; Caloiero, 2014, 2015).

In addition to the changes in the climatic features, the literature also focuses on the analysis of historical DHE's scenarios (Brázdil et al., 2011; Bullón, 2011). Actually, this analysis can supply useful information for the management of future events, providing an overview of the critical sites during past events that, without preventive measures, can be damaged again in future events. This information can be useful in decision support, emergency management and implementation of prevention and response measures. Moreover, they can play an important theoretical guiding role in meteorological disaster prediction, and future disaster prevention and reduction (Guan et al., 2015). In fact, an insight into past disasters allows assessing the performances of multiple mitigation strategies (Day and Fearnley, 2015) and, consequently, to help in the management of future events in which the simultaneous occurrence of landslides and floods must be taken into account. Especially for floods frequency estimation, the value of historical data is generally recognised in different countries, but practical methods for systematic and routinely inclusion of these data into risk analysis are rarely available, even though harvesting data on past extreme events could improve the reliability of flood risk assessments (Kjeldsen et al., 2014). Additionally, the analysis of historical DHE that affected a region offers didactic information to share with the population in order to improve the consciousness of risks affecting the areas in which they live, or can be used to calibrate loss estimation models (Papathoma-Köhle et al., 2015).

This study compares two events that affected the same area at a temporal distance of 15 years, highlighting similarities and differences in triggering rain, resulting damage and emergency management practices. In the Sect. 2, we summarise the methodology pointed out in previous papers to classify DHE according to severity of both triggering rain and resulting effects. Section 3 introduces the study area, while Sects. 4 and 5 describe the two compared DHE. Then, Sect. 6 presents the analytical comparison of the studied events, and Sect. 7 draws some conclusive remarks.

\section{Methodology}

To perform the comparison of two DHE, we have to take in mind that each event presents two components: the rain and the damage indirectly caused by rain, by means of phenomena as landslides and floods. Unfortunately, in the study area there are not hydrometric data that can be included in the analysis. For this reason, in order to perform this comparison we applied the methodology proposed in Aceto et al. (2016), based on the assessment of a damage score and a rainfall score combined to represent the exceptionality of the events. To assess the damage score, we evaluate three damage indicators (IDA, DI, and NoV). The Index of Damaged Area (IDA) is the sum of the areas of the damaged municipalities divided by the area of the region. It is the percentage of regional area that was damaged and represents a proxy of the actual damaged area. Obviously, the antecedent condition, i.e. in terms of terrain saturation, and the vulnerability and the resilience of the territory of the region are crucial elements affecting the level of damage of a DHE. In fact, the characteristics of Calabrian towns and villages in the past were different. For example, one of the most damaging DHE occurred in Calabria on 1953, and killed around 80 people. Several victims died in shacks realized to shelter people affected by previous DHE, which occurred just two years before, on 1951. Because of damage caused by the 1953 DHE, two villages (Brancaleone Superiore and Caulonia hamlet) were definitively abandoned (Petrucci and Pasqua, 2014). The Damage Index (DI) is a relative evaluation of direct damage. According to the elements damaged in the Calabria region throughout the historical series of regional DHEs, the damageable elements are sorted into seven types (roads and railways, houses, public buildings, services, productive activities, hydraulic works, and people) and their values range from 0 to 1 , on an arbitrary scale, while the levels of loss are set as: $1=$ high; $0.75=$ medium high; $0.5=$ medium; and $0.25=$ low. The sum of the products of the damaged elements by the respective levels of loss is the DI value, which is finally multiplied by a scale factor of 10 to avoid decimal values. The Number of Victims (NoV) is used as a further indicator of damage severity. Finally, the damage score $\left(D_{\text {score }}\right)$ is evaluated as in the Eq. (1), where $\mathrm{IDA}_{j}, \mathrm{DI}_{j}$ and $\mathrm{NoV}_{j}$ are the damage indicators of the event $j$, and $\mathrm{IDA}_{\max }, \mathrm{DI}_{\max }$ and $\mathrm{NoV}_{\max }$ are the maximum value of each damage indicators evaluated basing on the historical series of severest Calabrian DHEs:

$D_{\text {score }}=\left(\frac{\mathrm{IDA}_{j}}{\mathrm{IDA}_{\max }}+\frac{\mathrm{DI}_{j}}{\mathrm{DI}_{\text {max }}}+\frac{\mathrm{NoV}_{j}}{\mathrm{NoV}_{\text {max }}}\right) / 3$

For any further and detailed information about the evaluation of the damage indicators, the interested reader can easily refer to Aceto et al. (2016).

The Rainfall Score $\left(R_{\text {score }}\right)$ (Caloiero et al., 2014; revised by Aceto et al., 2016) is based on the return period $(T)$ of 


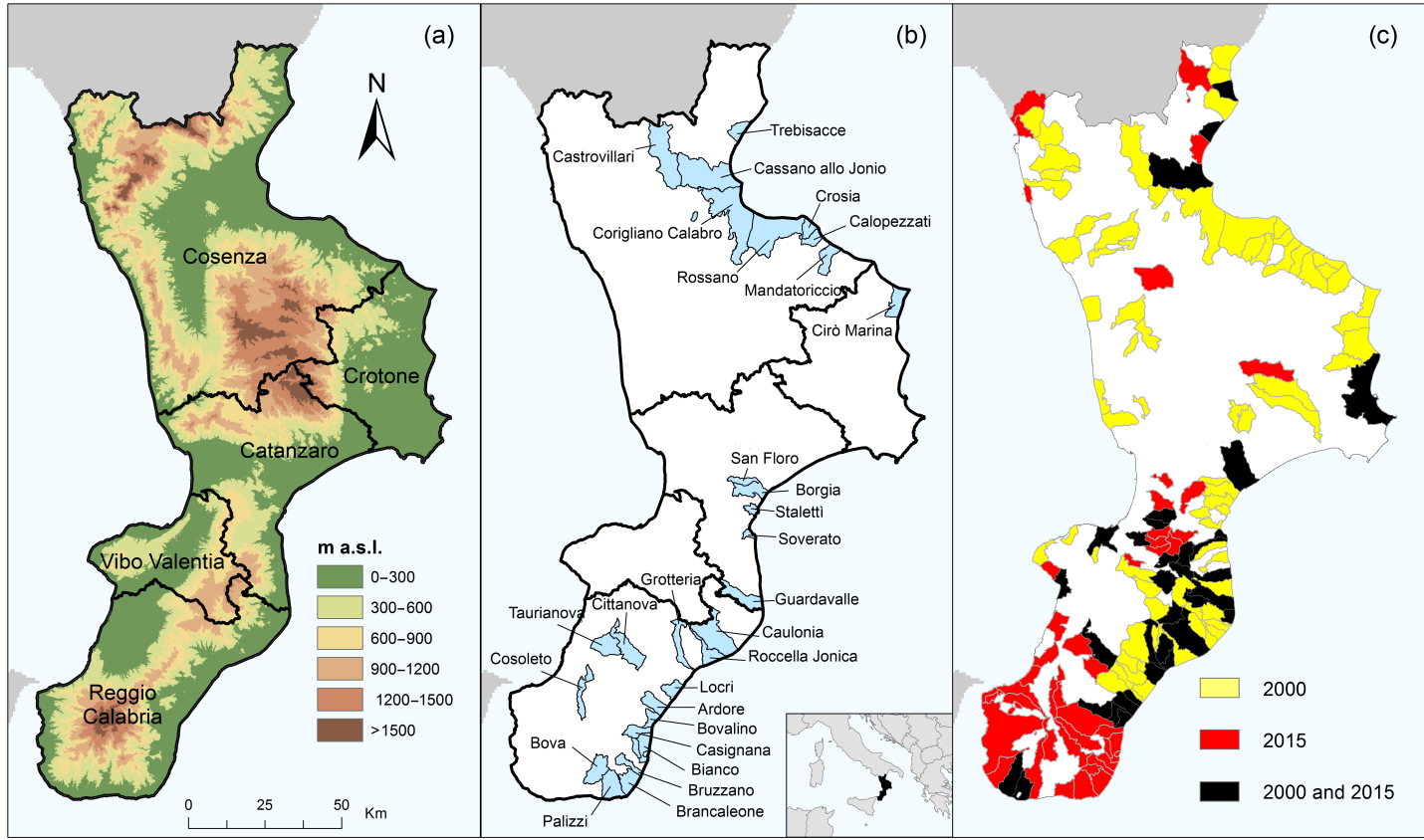

Figure 1. (a) Digital Elevation Model of the study area and regional provinces (Reggio Calabria, Vibo Valentia, Catanzaro, Crotone and Cosenza; (b) Map of the main municipalities damaged during the 2000 and the 2015 DHE and cited in the text; (c) Map of all the municipalities damaged during the 2000 (yellow) and the 2015 (red) DHE and during both the events (black).

the maximum daily rain recorded in each gauge during the days in which the damage event occurred. For each event, given a series of return period classes (selected according to the ones used in the Calabrian Hydro-geological Plan), the $R_{\text {score }}$ is calculated by evaluating the percentage of gauges falling within these classes, as in the Eq. (2):

$R_{\text {score }}=c_{0} \cdot \frac{\sum_{i=1}^{n} i \cdot P(T)_{i}}{\sum_{i=1}^{n} P(T)_{i}}$

where $n$ is the number classes, $i$ is a return period class, $P(T)_{i}$ is the percentage of gauges falling within each $i$ class, and $c_{0}$ is a graphic scale factor.

Basing on the combinations of $D_{\text {score }}$ and $R_{\text {score }}$, DHE can be classified as:

A. Ordinary events, characterized by low damage and rain values;

B. Extraordinary events, characterized by very high rainfall severity and moderately low damage levels;

C. Catastrophic events, showing severe damage caused by not extraordinary rainfall;

D. Major catastrophic events, showing high damage triggered by exceptional rain.

\section{Study area}

Located at the toe of the Italian peninsula, Calabria has a surface of $15080 \mathrm{~km}^{2}$; on average, its altitude is $597 \mathrm{~m}$ a.s.l., and its tallest relief is $2266 \mathrm{~m}$ a.s.l. The reliefs over $500 \mathrm{~m}$ a.s.l. high occupy $42 \%$ of the regional area, while hills between 50 and $500 \mathrm{~m}$ a.s.l. cover $49 \%$ of the territory, and only $9 \%$ of the region is under $50 \mathrm{~m}$ a.s.l. (Fig. 1a). The rugged morphology is due to the still active tectonic uplift that has been started in Quaternary. The geological structure is made of allochthonous crystalline rocks (Palaeozoic to Jurassic), stacked during the middle Miocene (Tortorici, 1982) over carbonate units (Ogniben, 1973), with Neogene flysch filling the tectonic depressions. Tectonic stresses and climatic conditions worsened the rocks characteristics, and disposed slopes to mass movements. Still due to the rapid uplift, the fluvial system is mainly made of ephemeral streams that cannot be gauged. Actually they are dry during summer and undergo severe flash floods in autumn-winter: during floods, active channels move from side to side of the riverbed, making difficult to find the right place to install the gauges. The climate is Mediterranean, presenting sharp contrasts due to the position of the region within the Mediterranean Sea and its orography (Coscarelli and Caloiero, 2012). Specifically, warm air currents coming from Africa and high temperatures affect the east side, leading to short and heavy rainfall, while on the west side, western air currents cause milder temperatures and higher precipitation. Cold and snowy winters and fresh summers with some precipitation are typical of the in- 


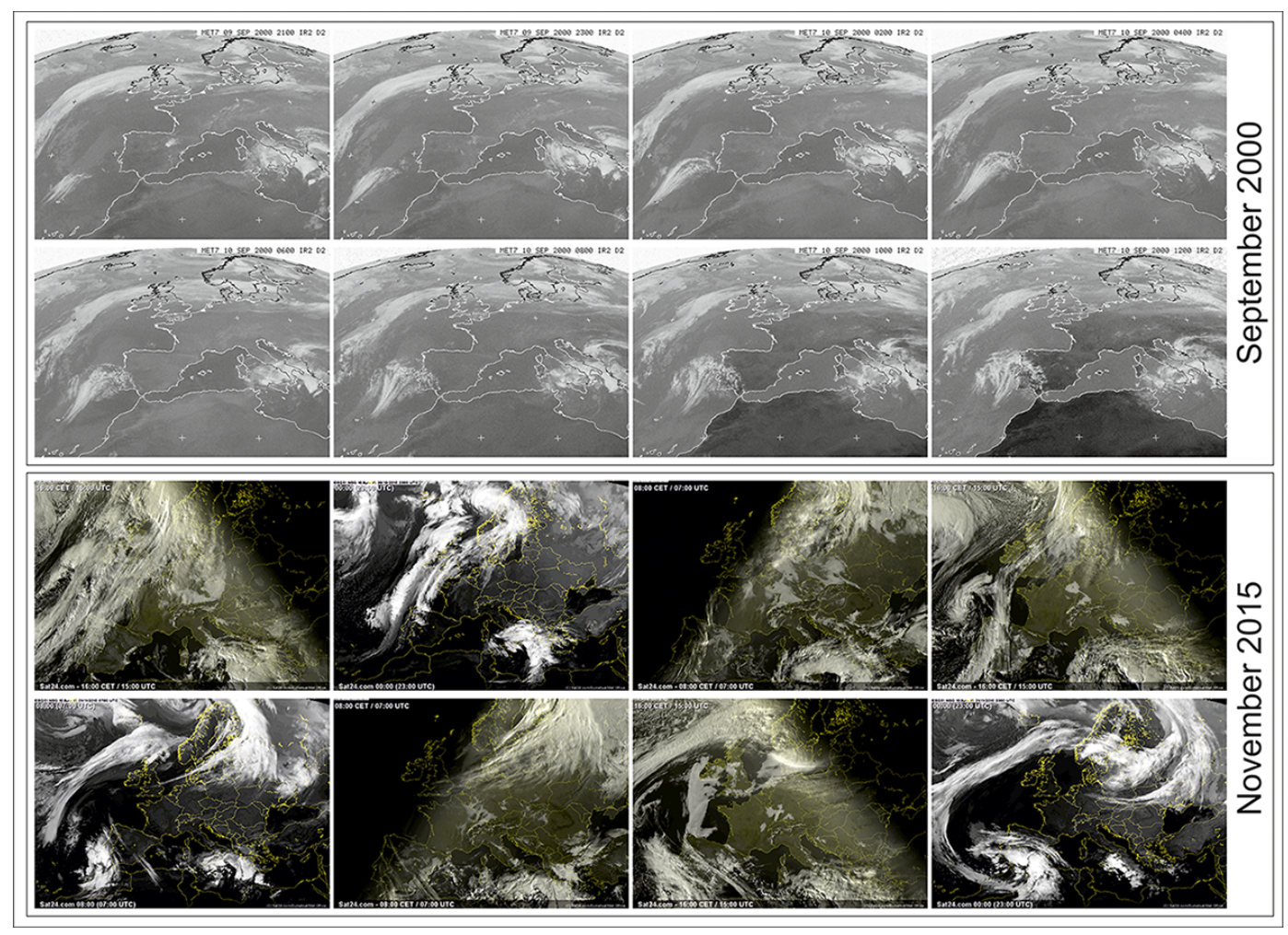

Figure 2. Meteorological framework of the western Mediterranean area during the 2000 and 2015 DHE.

ner sectors (Caloiero et al., 2015). Numerical simulations of severe weather showed the crucial role played by orography, which enhances rainfall in localized spots (Federico et al., 2003a, b) or forces secondary cyclogenesis which persists over the east side (Federico et al., 2007). The frequent DHE have been causing damage and victims throughout the years (Petrucci and Pasqua, 2012), as highlighted by both historical research (Petrucci and Versace, 2005, 2007; Palmieri et al., 2011; Gullà et al., 2012; Pasqua and Petrucci, 2016), and reports about more recent events (Petrucci et al., 2010; Caloiero and Petrucci, 2014).

\section{The event of September 2000}

The event occurred on September 2000 is known as Soverato event, after the name of the municipality in which 13 people were killed by the flood of Beltrame River. The event lasted three days, during which $27.0 \%$ of regional territory (109 municipalities, $3922.7 \mathrm{~km}^{2}$ ) was affected (Fig. 1c). The synoptic pattern of the event concerns: (a) an area of high pressure over central Europe, and (b) a low pressure over Sicily Island, originated from the merge of cold/dry air coming from North Atlantic and warm/moist air laying over the Mediterranean, particularly over the Strait of Messina and Calabrian east coasts. The mixing of these two air masses, having different temperature and humidity, originated severe precipitation that were amplified by the orographic effect. The result was a series of thunderstorms over the east coast, from north to south (Fig. 2). Fifty-six rain gauges (35.6\% of the gauges working during the event), managed by the regional Multi-Risk Functional Centre, recorded daily rain higher than $100 \mathrm{~mm}$ and, among these, 12 gauges recorded values higher than $200 \mathrm{~mm}$. The maximum value of daily rain recorded was $301.6 \mathrm{~mm}$, and it was recorded on the southeast sector of the region (Fig. 3). It was equal to about five times the September average monthly value of the region, and represents $27.1 \%$ of the mean total annual rainfall. As to what concerns the return period of maximum daily rainfall, 13 rain gauges showed return periods of $10 / 20$ years, 4 of 20/50 years, 2 of 50/100 years, 4 of 100/200 years and one gauge higher than 200 years (Fig. 3 ).

The central government, with different ordinances, allocated 491 million of euros to repair damage to public and private sectors (communication of Calabrian Civil Protection Unit).

\subsection{The 8 September 2000 scenario}

On 8 September, rainfall affected the eastern sector of the region, moving from south to north (Fig. 4). In 17 rain gauges, daily rainfall higher than $100 \mathrm{~mm}$ were detected, with a maximum of $208.7 \mathrm{~mm}$, having a return period 16.2 years. Damage affected the northern part of the region, mainly the 


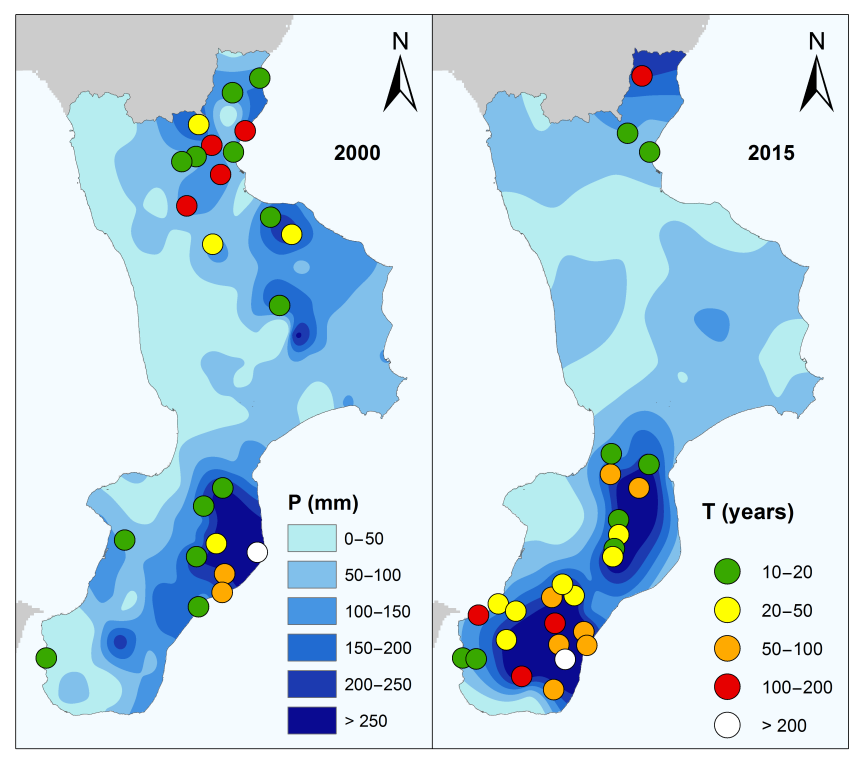

Figure 3. Maximum return period $(T)$ of daily rainfall recorded during each event at the gauges (circles coloured according to the legend) and maximum values of daily rain (shades of blue, according to the legend).

Cosenza province: urban floods damaged the roads and the cultivated areas. In the Castrovillari municipality (Fig. 1b), a daily rain of $86.2 \mathrm{~mm}$, with a $3 \mathrm{~h}$ cloudburst of $42.0 \mathrm{~mm}$, blocked the drainage system, causing urban flooding; fire brigades received about 30 calls for help, due to flooding of both houses and shops. Further damage occurred in the Cassano allo Jonio municipality (Fig. 1b), where a division of the hospital was flooded.

\subsection{The 9 September 2000 scenario}

On 9 September, the area affected by rainfall was wider (Fig. 4). The rain fell on the entire eastern side of the region, with daily values greater than $100 \mathrm{~mm}$ in 37 gauges, and greater than $200 \mathrm{~mm}$ in 5 gauges. The return period of daily rainfall was assessed between 100 and 200 years for 4 rain gauges. In the north sector, at 04:30 a.m. CET, near Crosia (Cosenza province), the Fiumarella Torrent flooded a house where four people were sleeping (Fig. 1b). A police officer rescued them, while the neighbours helped the other two people breaking the door and escape outside their flooded house. Moreover, in the same municipality (Fig. 1b), a river flooded the railway station with $3 \mathrm{~m}$ of water and debris. The State Road 106, the only north-south road of the east sector of the region, running along the coast and parallel to railway, was affected in several points. Near Mandatoriccio (Fig. 1b), a torrent flooded this road and dragged a car in transit, pushing it toward a guardrail and then to the sea. The couple inside was able to exit from car, and two police officers rescued them. In the Cosenza province: near Calopezzati (Fig. 1b), a river stripped more than $200 \mathrm{~m}$ of rail and the train traffic was interrupted. In the Rossano municipality (Fig. 1b), several families living in rural areas were isolated due to landslides or floods blocking the access roads. Three torrents flooded houses and road in the Trebisacce town (Fig. 1b), while the storm surge damaged the seafront. Near Corigliano Calabro (Fig. 1b), two person overwhelmed by a river breaking the levees were rescued by the police. To the east, in the Crotone province, more than 100 emergency calls due to floods and landslides were recorded. After an intense $30 \mathrm{~min}$ rain $(23.2 \mathrm{~mm})$, the road network near Cirò Marina (Fig. 1b) was invaded by mud eroded from adjacent slopes, blocking several motorists in transit. Moreover, the rain saturated the drainage system of the urban centre: the water, $50 \mathrm{~cm}$ high, flooded some houses and the post office, and fire brigades rescued people blocked inside it. In the southeast sector, some damage affected the Catanzaro province, with urban floods in Borgia (Fig. 1b), a touristic village flooded in Stalettì (Fig. 1b), and mud blocked traffic along the road network in Borgia and S. Floro municipalities (Fig. 1b). To the south, in the Reggio Calabria province, fire brigades and military corps received more than 500 emergency calls. The rivers outflowed and interrupted both the State Road 106 and the railway in several points. In innermost villages of the east side, even landslides damaged roads and houses. Severe damage occurred in Roccella Jonica (Fig. 1b), where the rivers dragged more than 100 cars along the city roads, and about 10 of them for about $500 \mathrm{~m}$ up to the sea. About 100 shops were flooded. Rivers outflowed interrupted the railway traffic and flooded about 100 houses, thus 300 families were temporary evacuated. A severe storm surge damaged six beach resorts, disrupted tens of small ships, and the sea advanced for about $50 \mathrm{~m}$ toward the hinterland. A landslide, originating from a slope $100 \mathrm{~m}$ high, falls on a group of houses disrupting two of them: the owners were just escaped outside. Telephonic and electric lines were interrupted.

\subsection{The 10 September 2000 scenario}

On 10 September, intense rainfall mainly focused on the middle-south east sector (Fig. 4). In 30 rain gauges, daily rainfall was higher than $100 \mathrm{~mm}$, and in 6 gauges was higher than $200 \mathrm{~mm}$. The maximum daily rainfall was $301.6 \mathrm{~mm}$, with a return period greater than 500 years. In the Soverato municipality (Catanzaro province), in the area where the maximum daily rain was recorded, the severest effects on people occurred (Fig. 1b). At 04:00 a.m., the disastrous flood of the Beltrame River swept away the campsite named Le Giare and located just on the riverside, where 53 people were sleeping, including 17 handicapped persons. The survivors rescued themselves by climbing on the roofs of the bungalows or on willow trees. They described the great sense of confusion related to the darkness and the noise of the flood inundating the area. As a result, 13 people died, five of whom were handicapped persons. The day after, the campsite appeared as submerged by more than one meter of mud that 


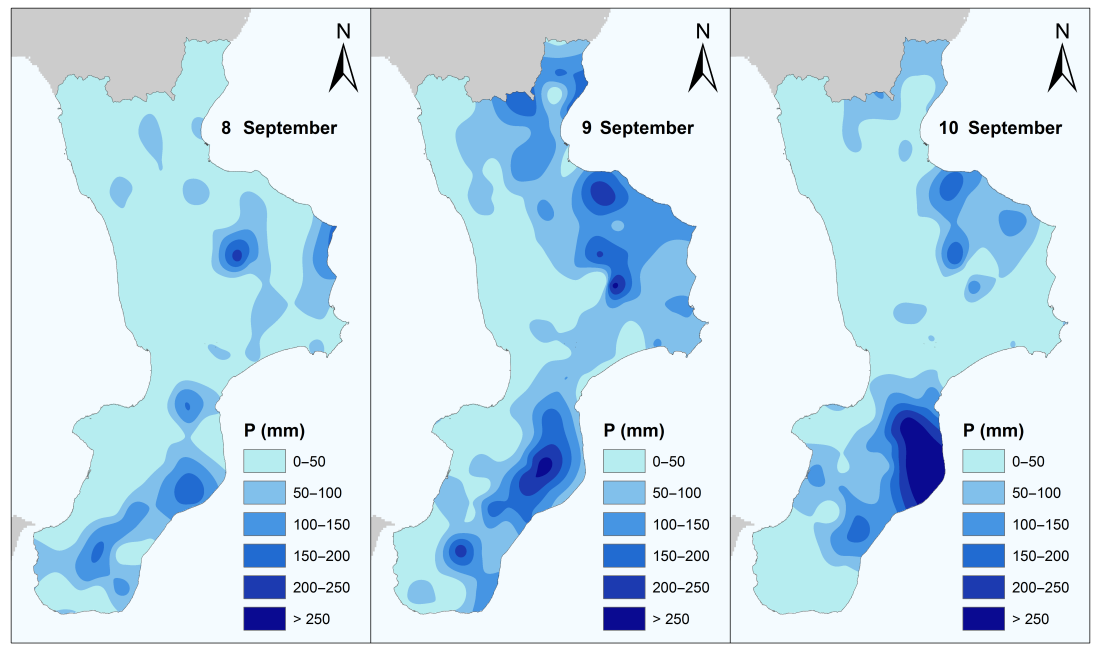

Figure 4. Spatial and temporal distribution of the daily rainfall for the September 2000 event.

strongly complicated the work of more than 300 people involved in the rescue operations. In the same province, the Guardavalle municipality (Fig. 1b) remained isolated due to floods and landslides that interrupted the access roads. Moreover, some families were evacuated due to landslides, the kindergarten was submerged by $5 \mathrm{~m}$ of debris, the elementary school was inundated, and cultivated fields disrupted. Almost the entire Reggio Calabria province was affected by daily rain higher than $200 \mathrm{~mm}$ : landslides blocked roads connecting the innermost municipalities to the coast, several torrents isolated rural settlements, and both the electric and telephonic lines were interrupted.

\section{The event of 2015}

The second analysed event occurred between 30 October and 1 November 2015, and affected 79 municipalities of Calabria $(19.3 \%)$, with an area of $2578.9 \mathrm{~km}^{2}(17.0 \%$ of regional area) (Fig. 1c). While an area of high pressure with values up to $1040 \mathrm{hPa}$ was located over central Europe, a low pressure moved from central Tyrrhenian Sea towards the Strait of Sicily, causing a marked instability over southern Italy. Particularly on the east coast, low-level eastern flow enhanced intensity and frequency of storms (Fig. 2). 39 rain gauges recorded daily rain higher than $100 \mathrm{~mm}$, but 21 reached rain values higher than $200 \mathrm{~mm}$, and 4 higher than $300 \mathrm{~mm}$, with a maximum value of $370.4 \mathrm{~mm}$ (Fig. 3). These values, registered on the southeast sector of the region, were exceptional for the period, with maximum daily values more than three times than the average monthly value. Moreover, in 3 rain gauges, in just one day, more than $33 \%$ of the mean annual rainfall was recorded. In 8 rain gauges, daily rain showed return periods of 10/20 years, in 7 of 20/50 years, in 7 of $50 / 100$ years, in 4 of 100/200 years, and in one rain gauge showed a value higher than 200 years (Fig. 3).
The central government, with different ordinances, allocated about 130 million of euros to repair damage to private and public sectors (communication of Calabrian Civil Protection Unit).

\subsection{The 30 October 2015 scenario}

On 30 October, the Calabrian Civil Protection Unit issued an alert for possible intense rain and dangerous effects to 285 municipalities (70\% of the 409 municipalities of the region). 162 municipalities $(40 \%)$ received the alert for possible high severity damage, 54 (13\%) for medium severity and $69(17 \%)$ for possible low severity damage (AA.VV., 2015). As a result, several majors commanded the closure of all the schools for 30 and 31 October, thus reducing the number of people exposed to risk along the road network, or outdoors. In this day, the very north eastern side of the region was affected by severe rain, with daily values greater than $50 \mathrm{~mm}$ in 4 rain gauges, greater than $100 \mathrm{~mm}$ in one gauge, and greater than 200 in another one gauge, reaching a return period of about 200 year (Fig. 5). Fortunately, only few damage occurred in this area, and in particular in the municipality of Trebisacce (Fig. 1b), where the urban drainage system was blocked and the roads were partially flooded.

\subsection{The 31 October 2015 scenario}

On 31 October, the rain concentrated on the southern part of the region, mainly affecting the eastern sector (Fig. 5). In 27 rain gauges, daily rainfall was greater than $100 \mathrm{~mm}$; in 8 gauges it was higher than $200 \mathrm{~mm}$, while the maximum daily rain was $364.6 \mathrm{~mm}$. Despite the high rainfall values, only in one gauge a return period of 50/100 years was detected. As a result, 32 municipalities were affected (about $40 \%$ of the municipalities damaged by the whole event). Along the east coast, in the Cosenza, Catanzaro and Reggio 


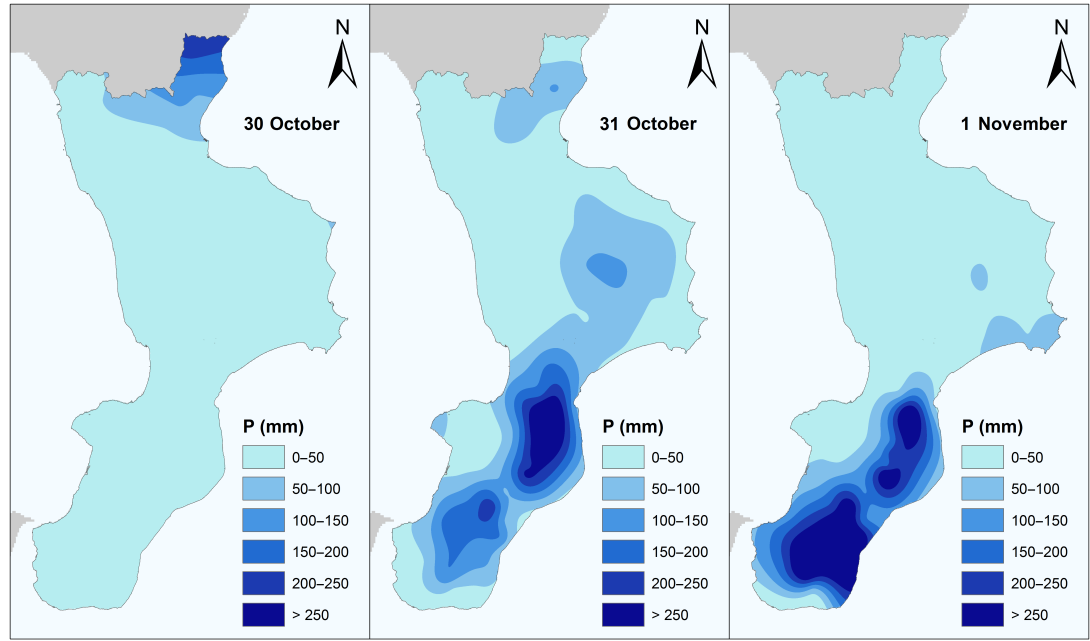

Figure 5. Spatial and temporal distribution of the daily rainfall for the 2015 event.

Calabria provinces, the effects were the flooding of urban sectors in which intense rain and/or debris carried by rain erosion obstructed drainage systems. As a total, 71 people were evacuated due to landslides or floods. In the municipality of Taurianova (Reggio Calabria), the severest effect on people occurred: a man, who was fording a river on a small bridge, died trapped in his car, dragged by the flood of a stream (Fig. 1b). Before drown, he broken the windscreen of the car, allowing to his daughter to exit from the car and save her life, helped by some residents. Along the coast, near Brancaleone (Fig. 1b), the simultaneous action of the flood of the river Bruzzano and the intense storm surge broken the railway and the State Road 106. Four people in two cars passed on the State Road just before the road collapse. Two militaries, on a warm-up lap, helped the people to exit from cars and save their lives, while, in a few minutes, the road broken definitely and the two cars were swept away by the sea. In Casignana (Fig. 1b), a landslide broke the basin of the garbage dump, thus causing the spilling of percolate in the surrounding area and into the sea. In the area of Locri, Ardore, Bovalino, Casignana and Bianco municipalities (Fig. 1b), where the rain reached daily values higher than $300 \mathrm{~mm}$, several torrents outflowed, flooding houses, shops and cultivated fields, and some rural settlements were isolated due to landslides blocking their access roads. In Reggio Calabria province, the strongest affected province, fire brigades, received about 200 calls from people trapped in either houses or cars by water and mud spilled along the road network. Strong wind (70-80 $\mathrm{km} \mathrm{h}^{-1}$ ) damaged electric lines and caused storm surges that damaged the seafront in several touristic villages.

\subsection{The 1 November 2015 scenario}

The 1 November the rain still insisted on the south sector, moving on the western side of the region (Fig. 5). In 13 rain gauges, daily rainfall was higher than $100 \mathrm{~mm}$ and, in 16 gauges, higher than $200 \mathrm{~mm}$ : the maximum value was $370.4 \mathrm{~mm}$, with a return period of almost 1000 years. In 12 gauges, the total amount of rain that fell between 31 October and 1 November was greater than $400 \mathrm{~mm}$, with a maximum value of $687.2 \mathrm{~mm}$, corresponding to a return period higher than 1000 years. Landslides, floods and storm surges damaged 21 municipalities. This phase was characterised by the precautionary evacuation of people in dangerous situations. In Cittanova (Fig. 1b), 20 persons were evacuated before the outflowing of Vacale River, potentially affecting their houses; in Cosoleto (Fig. 1b), two houses were evacuated just before a debris flow affected them, and the west side railway was precautionary closed, due to the threat of a torrent flood. Further people evacuated in the villages of Grotteria (38), due to a landslide, Bova (1), Bovalino (14), Caraffa del Bianco (1), Casignana (1), Caulonia (15), and Palizzi (1) (AA.VV., 2015).

\section{Comparison between the 2000 and 2015 events}

Both the DHE were characterized by a 3-day duration, but they occurred in two months characterised by different climatic features, in fact, in Calabria the September average daily rain in is $64.1 \mathrm{~mm}$, while in October it rises to $123.3 \mathrm{~mm}$. The total rain, expressed as $\mathrm{mm}$ no. of gauges ${ }^{-1} \mathrm{~km}^{-2}$, was higher for the 2015 than for the 2000 event (Table 1). To facilitate the comparison, in Fig. 6 we presented the descriptive features of the two events as ratio between the 2015 and 2000 values. The red line marking the value " 1 " represents the case in which the value of 2015 was equal to the one of 2000. A value above or under this line, indicates that the analysed feature was higher in 2015 or in 2000, respectively. The diagrams of Fig. 6a, b, c, represent the features describing the rain event. Results show that 
Table 1. Summary of the rain characteristics of the 2000 and 2015 DHE.

\begin{tabular}{|c|c|c|c|c|}
\hline RAIN EVENT & \multicolumn{2}{|c|}{2000 DHE } & \multicolumn{2}{|c|}{2015 DHE } \\
\hline Event beginning & \multicolumn{2}{|l|}{$8 \mathrm{Sep}$} & \multicolumn{2}{|l|}{30 Oct } \\
\hline Event end & \multicolumn{2}{|l|}{$10 \mathrm{Sep}$} & \multicolumn{2}{|l|}{$1 \mathrm{Nov}$} \\
\hline Duration of the event (days) & \multicolumn{2}{|l|}{3} & \multicolumn{2}{|l|}{3} \\
\hline Total rain (mm no. of gauges ${ }^{-1} \mathrm{~km}^{-2}$ ) & \multicolumn{2}{|c|}{0.01124} & \multicolumn{2}{|c|}{0.01144} \\
\hline no. gauges working during the event & 157 & & \multicolumn{2}{|c|}{102} \\
\hline Gauges with daily rain (mm) & Number & $\%$ & Number & $\%$ \\
\hline $50-100(\mathrm{~mm})$ & 54 & 34.4 & 36 & 35.3 \\
\hline $100-200(\mathrm{~mm})$ & 44 & 28.0 & 18 & 17.6 \\
\hline$>200(\mathrm{~mm})$ & 12 & 7.6 & 21 & 20.6 \\
\hline Area affected by daily rain (mm) & Area $\left(\mathrm{km}^{2}\right)$ & $\%$ & Area $\left(\mathrm{km}^{2}\right)$ & $\%$ \\
\hline $50-100(\mathrm{~mm})$ & 5182.3 & 34.4 & 6607.1 & 43.8 \\
\hline $100-200(\mathrm{~mm})$ & 4275.2 & 28.4 & 2480.0 & 16.4 \\
\hline$>200(\mathrm{~mm})$ & 963.8 & 6.4 & 2044.1 & 13.6 \\
\hline Gauges with return period of daily rain (years) & Number & $\%$ & Number & $\%$ \\
\hline $10 / 20$ (years) & 13 & 8.3 & 8 & 7.8 \\
\hline 20/50 (years) & 4 & 2.5 & 7 & 6.9 \\
\hline $50 / 100$ (years) & 2 & 1.3 & 7 & 6.9 \\
\hline $100 / 200$ (years) & 4 & 2.5 & 4 & 3.9 \\
\hline$>200$ (years) & 1 & 0.6 & 1 & 1.0 \\
\hline Maxima values of rain & Value & & Value & \\
\hline 1 day $(\mathrm{mm})$ & 301.6 & & 370.4 & \\
\hline 2 days $(\mathrm{mm})$ & 505.2 & & 687.2 & \\
\hline $1 \mathrm{~h}(\mathrm{~mm})$ & 74.6 & & 57.4 & \\
\hline $3 \mathrm{~h}(\mathrm{~mm})$ & 154.2 & & 107.8 & \\
\hline $6 \mathrm{~h}(\mathrm{~mm})$ & 206.4 & & 150.4 & \\
\hline Max daily rain/monthly average & 4.71 & & 3.01 & \\
\hline Max two-day rain/monthly average (mm) & 7.89 & & 5.59 & \\
\hline Max daily rain as $\%$ of mean annual rain & 27.1 & & 33.2 & \\
\hline
\end{tabular}

The percentage of gauges with daily rain higher than some thresholds and with return period of daily rain falling within prefixed classes is evaluated with reference to the rain gauges working in 2000 (157) and 2015 (102). The percentage of area affected by daily rain higher than some thresholds is evaluated following the areas of Fig. 1 and considering the area of the region $\left(15080 \mathrm{~km}^{2}\right)$.

the area affected by daily rain between 50 and $100 \mathrm{~mm}$ was higher in 2015, and the area with more than $200 \mathrm{~mm}$ was considerably larger for 2015 than for 2000, showing the greater severity of the 2015 event in terms of stronger daily intensity on a larger area (Fig. 6a). From the analysis of the maxima (Fig. 6b), both 1-day and 2-day values were greater in 2015, while 1,3 , and $6 \mathrm{~h}$ were considerably higher in 2000 than in 2015. Thus, the 2000 event was characterised by stronger rain intensity, which caused flash floods in some small basins of the region such as the Beltrame River, while the 2015 event by a greater rain duration, as confirmed by the 2-day rain, equals to 505.2 and $687.2 \mathrm{~mm}$ respectively. The latter value is particularly relevant, being more than five times the average October monthly rain, and about $60 \%$ of the mean annual rainfall. As far as the exceptionality of return period of daily rain, the compared events were equals in terms of number of gauges recording return periods of 100/200 years and greater than 200 years. Nevertheless, 2015 event showed the number of gauges with return periods of 20/50 years and $50 / 100$ years considerably greater than 2000 event (Figs. 3; $6 c)$.

From a geographical point of view, both the event focused on the east regional sector, as the majority of damaging event affecting the region, generally caused by a barometric minimum moving from the Tyrrhenian Sea, to the South of Italy (Petrucci and Polemio, 2009). Nevertheless, the 2000 event affected almost the entire region in a spotty way, while the 2015 event mainly hit the southeast sector (Fig. 7). As regards the damage, the 2000 event affected an area larger than 2015 event, and accordingly, a greater number of phenomena caused damage (Fig. 6d) to the different types of vulnerable elements (Fig. 6e), even if services and roads and rail- 
Area affected by daily rain

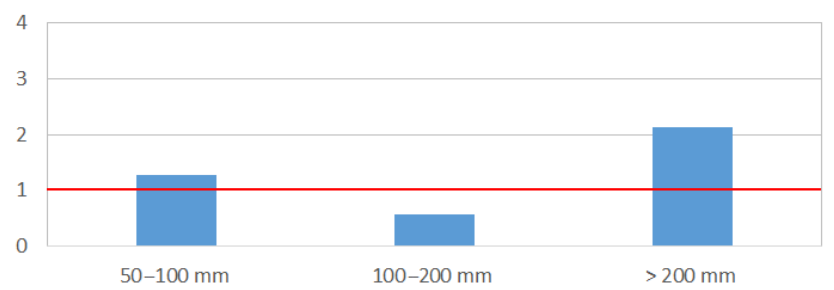

Maxima values of rain

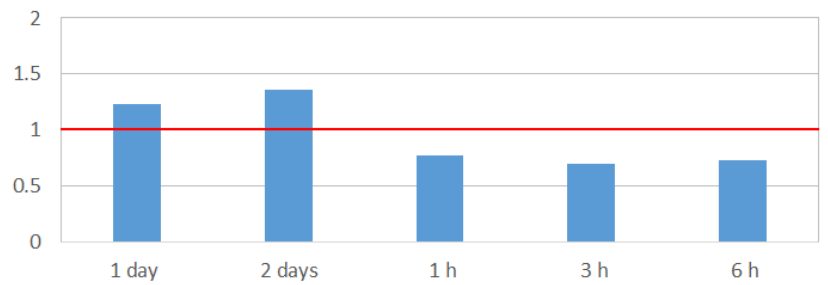

Number of gauges falling within the return period classes

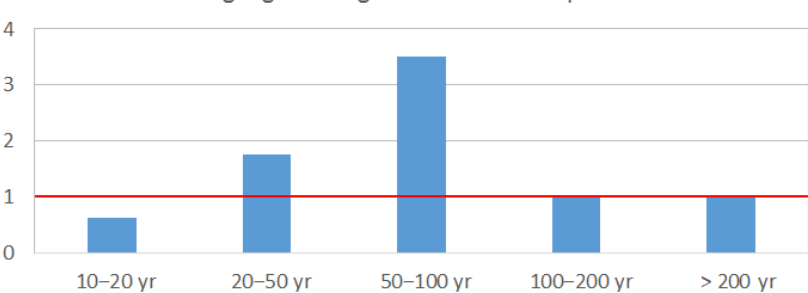

(c)
Number of records of damage

(d)

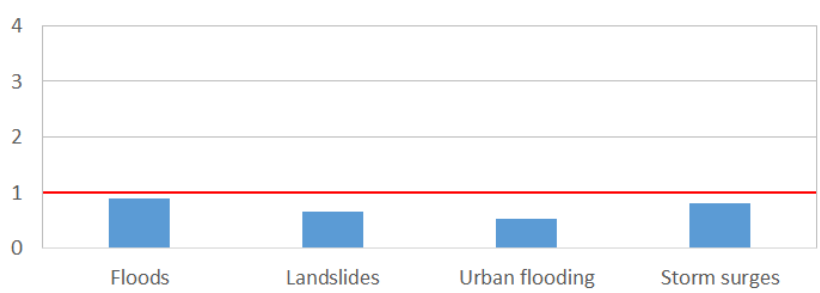

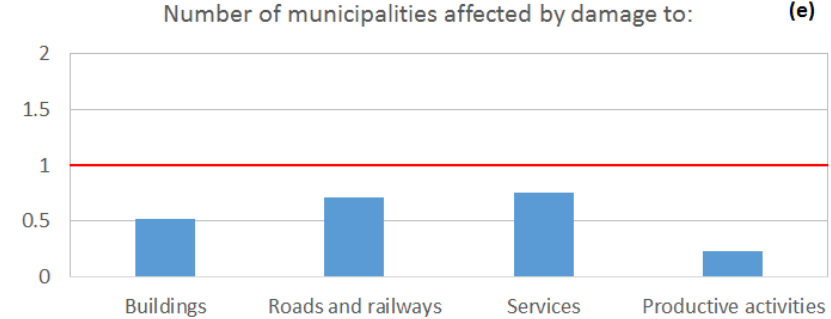

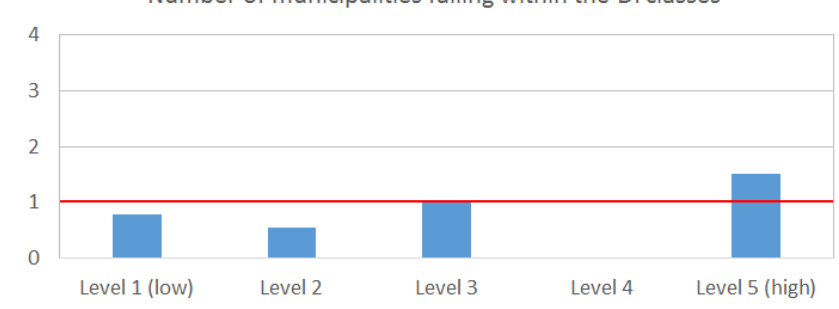

Figure 6. Events comparison by means of the ratio between the 2015 and the 2000 values reported in the titles of diagrams.

ways were the most affected types. This is confirmed by the amount of funds allocated to repair damage, larger in 2000 than in 2015 event.

The damage in 2000 event (Table 2) was strongly increased by the high number of victims (13) with respect to 2015 (1), even if all the victims of 2000 occurred in a single accident that could be avoided if the campsite was located far from the river and/or the event was forecasted in advance allowing people evacuation.

According to the data gathered and indexes assessed to characterize both RE and DE, using expressions (1) and (2), the 2000 event was classified as catastrophic while 2015 as major catastrophic event (Fig. 8). This result is mainly due to the value of the $R_{\text {score }}$, which is higher in 2015 than in 2000, while an opposite behaviour has been obtained for the $D_{\text {score. In practice, at daily scale, the rainfall event was }}$ more severe in 2015 than in the 2000, even if damage caused by the 2000 event was higher than in 2015 case. One factor that can explain this difference is the management of the events, especially in terms of alert and evacuation measures. Actually, in 2000, Civil Protection in Italy had an organisation different from nowadays, both at national and regional level: there were any alert system for meteorological events, and thus no alert for possible damaging rain was issued to the central-southern sector of the region before the event. The 2000 event represented a break: after the Sover-

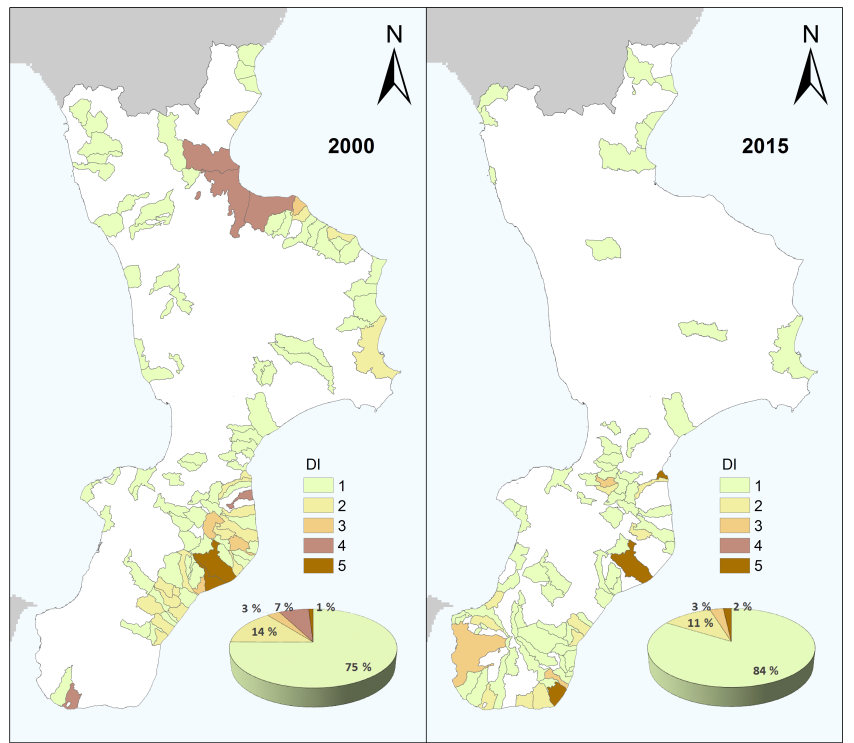

Figure 7. Classification of municipalities of Calabria according to the classes of Damage index (DI) listed in the legend. 1: low damage; 2: low-medium damage; 3: medium damage; 4: high damage; 5: very high damage. 
Table 2. Summary of the damage characteristics of the 2000 and 2015 DHE.

\begin{tabular}{|c|c|c|c|c|}
\hline DAMAGE EVENT & \multicolumn{2}{|c|}{2000 DHE } & \multicolumn{2}{|c|}{2015 DHE } \\
\hline Governmental fund to repair damage (EUR M) & \multicolumn{2}{|c|}{491} & \multicolumn{2}{|c|}{$130^{*}$} \\
\hline N. of victims & \multicolumn{2}{|c|}{13} & \multicolumn{2}{|c|}{1} \\
\hline Damaged municipalities & \multicolumn{2}{|c|}{109} & \multicolumn{2}{|c|}{79} \\
\hline Area affected $\left(\mathrm{km}^{2}\right)$ & \multicolumn{2}{|c|}{3922.7} & \multicolumn{2}{|c|}{2578.9} \\
\hline IDA & \multicolumn{2}{|c|}{27.0} & \multicolumn{2}{|c|}{17.0} \\
\hline Municipalities affected by damage to: & Number & $\%$ & Number & $\%$ \\
\hline Buildings & 69 & 63.3 & 36 & 45.6 \\
\hline Roads and railways & 109 & 100.0 & 78 & 98.7 \\
\hline Services and hydraulic works & 24 & 22.0 & 18 & 22.8 \\
\hline Productive activities & 106 & 97.2 & 25 & 31.6 \\
\hline Records of damage caused by: & Number & $\%$ & Number & $\%$ \\
\hline Floods & 41 & 19.6 & 37 & 26.4 \\
\hline Landslides & 75 & 35.9 & 49 & 35.0 \\
\hline Urban flooding & 77 & 36.8 & 41 & 29.3 \\
\hline Storm surges & 16 & 7.7 & 13 & 9.3 \\
\hline Municipalities with DI classified as: & Number & $\%$ & Number & $\%$ \\
\hline Level 1 (low) & 80 & 74.1 & 63 & 79.7 \\
\hline Level 2 & 18 & 16.6 & 10 & 12.7 \\
\hline Level 3 & 3 & 2.8 & 3 & 3.8 \\
\hline Level 4 & 5 & 4.6 & 0 & 0.0 \\
\hline Level 5 (high) & 2 & 1.9 & 3 & 3.8 \\
\hline
\end{tabular}

The percentage of damaged municipality is assessed with reference to the total number of municipalities affected by the DHE in 2000 (109) and 2015 (79). The percentage of records of damage is calculated with reference to the total number of records of the two events, 209 and 140 in 2000 and 2015 respectively. Finally, the percentage of municipalities falling within the different DI classes is evaluated considering the total number of municipalities affected by the DHE. * EUR 130 M funded until December 2016

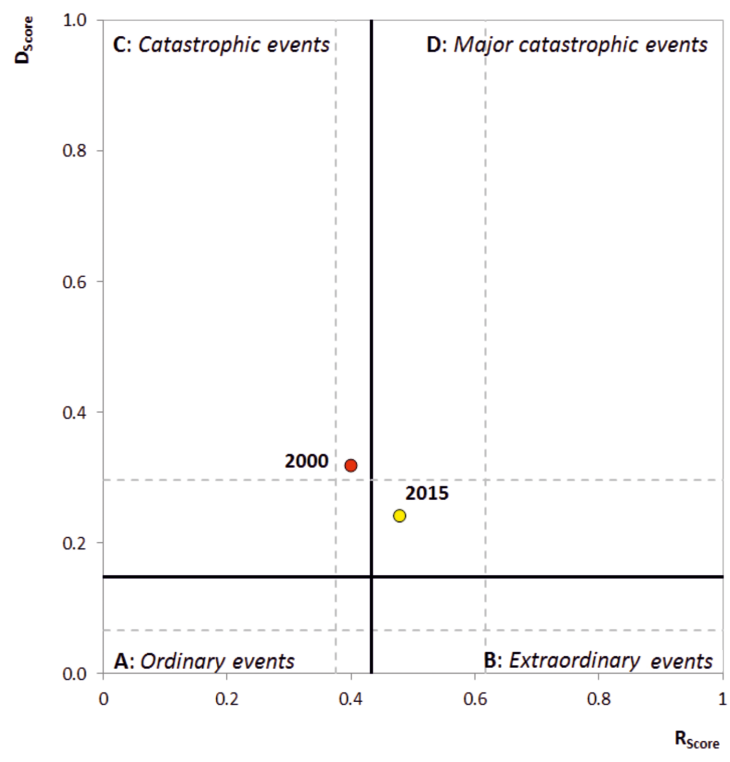

Figure 8. Chart classifying the analysed events according to their magnitude. $D_{\text {score }}$ and $R_{\text {score }}$ are described in Sect. 3. ato event, the Italian government recognised the urgent need of a more strength and effective organisation of Civil Protection regional units, based on the support of real-time meteorological data and effective rainfall forecasting systems. In fact, after this event, the Civil Protection Ordinance no. 3081 was issued and it established the Multi-Risk Functional Centre (Regional Agency for Environment Protection), a regional office in charge to systematically collect and elaborate data measured by hundreds of automatic weather meteorological stations of the regional gauges network. In 2015, the MultiRisk Functional Centre, after the information transmitted by the National Office of Civil Protection and the outcomes of their meteorological data elaborations, transmitted official bulletins to Civil Protection, forecasting the intense rain approaching. Basing on this information, the Civil Protection Unit alerted majors of the municipalities where rain was forecasted, allowing them to be prepared to the emergency management and thus avoiding greater damage.

The Civil Protection rainfall forecasting systems is then paramount in a region such as Calabria, which is characterized by small basins and influenced by orographic precipitation that can cause flash floods. In fact, currently, predictions of flash floods rely predominantly on the weather forecast, 
although the time and the place where heavy rain may occur are still difficult to predict. Indeed, meteorological forecast gives the overall information that a given region can be affected by heavy rainfall causing flash floods in small basins. In order to overcome such a problem, after 2001, in Calabria, when a meteorological alert is issued, each of the majors of the municipalities involved by the alert starts a monitoring of the flash flood prone basins and the critical points belonging to their municipality, such as bridges and underpasses, in order to avoid causalities.

\section{Conclusions}

This work presents a comparative analysis of two events, both affecting Calabria region (southern Italy) at a distance of 15 years, on 2000 and 2015. In particular, a methodological approach is proposed, by organising a systematic comparative analysis of all the qualitative and quantitative features that are used to describe the analysed events, even using severity indexes introduced in previous works. The same approach can be used to describe and compare similar events occurred in different countries and epochs.

The analysis highlight the following points:

The 2000 event was classified as catastrophic, according to the classification proposed by Aceto et al. (2016), mainly due to the exceptionality of the damage.

1. It presented the highest rain intensities in 1,3 and $6 \mathrm{~h}$, concurring to trigger flash floods, storm surges and landslides.

2. It caused a disastrous flash flood in Soverato, on the middle east coast, that killed 13 persons in a campsite nearby the river Beltrame.

The 2015 event was classified as major catastrophic, according to the classification proposed by Aceto et al. (2016), mainly due to the exceptionality of the daily rain.

1. It presented the highest total amount of rain and the highest values of daily intensity on a larger area: the two days rain reached five times the regional October monthly average, mainly triggering floods and storm surges

2. In this event, an effective management of pre-event phases, with the issuing of meteorological alert, and the emergency management, with the preventive evacuation of people in hazardous situations due to landslides or floods, contributed to reduce the number of victims.

Data availability. Damage data are freely available from the PEOPLE database: https://doi.org/10.17632/mz2b8f8ys7.1 (Petrucci et al., 2017).

Rainfall data are freely available from the Multi-Risk Functional Centre of the Regional Agency for Environment Protection online database: http://www.cfd.calabria.it/index.php/dati-stazioni/ dati-storici.

Competing interests. The authors declare that they have no conflict of interest.

Special issue statement. This article is part of the special issue "Hydro-related hazardous events and their consequences in the Mediterranean area: knowledge management adaptation". It is a result of the 15th Plinius Conference on Mediterranean Risks, Giardini Naxos, Italy, 8-11 June 2016.

Acknowledgements. We are grateful to the Editor and the Referees for the useful suggestions that improved the paper.

Edited by: Giuseppe Tito Aronica

Reviewed by: Giovanni Ravazzani and one anonymous referee

\section{References}

AA.VV.: Rapporto di evento precipitazioni del 30 ottobre-2 novembre 2015, Regione Calabria, UOA Protezione Civile and Autorità di Bacino, 2015.

Aceto, L., Caloiero, T., Pasqua, A. A., and Petrucci, O.: Analysis of damaging hydrogeological events in a Mediterranean region (Calabria), J. Hydrol., 541, 510-522, https://doi.org/10.1016/j.jhydrol.2015.12.041, 2016.

Alexander, L. V., Zhang, X., Peterson, T. C., Caesar, J., Gleason, B., Klein Tank, A. M. G., Haylock, M., Collins, D., Trewin, B., Rahimzadeh, F., Tagipour, A., Kumar Kolli, R., Revadekar, J.V., Griffiths, G., Vincent, L., Stephenson, D. B., Burn, J., Aguilar, E., Brunet, M., Taylor, M., New, M., Zhai, P., Rusticucci, M., and Vazquez Aguirre, J. L.: Global observed changes in daily climate extremes of temperature and precipitation, J. Geophys. Res., 111, D05101, https://doi.org/10.1029/2005JD006290, 2006.

Allan, R. P. and Soden, B. J.: Atmospheric warming and the amplification of precipitation extremes, Science, 321, 1481-1484, https://doi.org/10.1126/science.1160787, 2008.

Brázdil, R., Řezníčková, L., Valášek, H., Havlíček, M., Dobrovolný, P., Soukalová, E., Řehánek, T., and Skokanová, H.: Fluctuations of floods of the River Morava (Czech Republic) in the 1691-2009 period: interactions of natural and anthropogenic factors, Hydrolog. Sci. J., 56, 468-485, https://doi.org/10.1080/02626667.2011.564175, 2011.

Bullón, T.: Relationships between precipitation and floods in the fluvial basins of Central Spain based on documentary sources from the end of the 16th century, Nat. Hazards Earth Syst. Sci., 11, 2215-2225, https://doi.org/10.5194/nhess-11-2215-2011, 2011.

Caloiero, T.: Analysis of daily rainfall concentration in New Zealand, Nat. Hazards, 72, 389-404, https://doi.org/10.1007/s11069-013-1015-1, 2014.

Caloiero, T.: Analysis of rainfall trend in New Zealand, Environ. Earth Sci., 73, 6297-6310, https://doi.org/10.1007/s12665-0143852-y, 2015. 
Caloiero, T. and Petrucci, O.: The Impact of Damaging Hydrogeological Events on urbanised sectors: The case of 19th November 2013 in Catanzaro (Italy), Proc. of the 3rd IAHR Europe Congress Porto, Portugal, 14-16 April, 2014.

Caloiero, T., Pasqua, A. A., and Petrucci, O.: Damaging Hydrogeological Events: a procedure for the assessment of severity levels and an Application to Calabria (Southern Italy), Water, 6, 36523670, https://doi.org/10.3390/w6123652, 2014.

Caloiero, T., Buttafuoco, G., Coscarelli, R., and Ferrari, E.: Spatial and temporal characterization of climate at regional scale using homogeneous monthly precipitation and air temperature data: An application in Calabria (southern Italy), Hydrol. Res., 46, 629646, https://doi.org/10.2166/nh.2014.022, 2015.

Caloiero, T., Coscarelli, R., Ferrari, E., and Sirangelo, B.: Trends in the Daily Precipitation Categories of Calabria (Southern Italy), Procedia Engineering, 162, 32-38, https://doi.org/10.1016/j.proeng.2016.11.008, 2016.

Chou, C. and Neelin, J.: Mechanisms of global warming impacts on regional tropical precipitation, J. Climate, 17, 2688-2701, https://doi.org/10.1175/15200442(2004)017<2688:MOGWIO>2.0.CO;2, 2004.

Coscarelli, R. and Caloiero, T.: Analysis of daily and monthly rainfall concentration in Southern Italy (Calabria region), J. Hydrol., 416-417, 145-156, https://doi.org/10.1016/j.jhydrol.2011.11.047, 2012.

Day, S. and Fearnley, C.: A classification of mitigation strategies for natural hazards: implications for the understanding of interactions between mitigation strategies, Nat. Hazards, 79, 1219, https://doi.org/10.1007/s11069-015-1899-z, 2015.

Durão, R. M., Pereira, M. J., Costa, A. C., Delgado, J., del Barrio, G., and Soares, A.: Spatial-temporal dynamics of precipitation extremes in southern Portugal: a geostatistical assessment study, Int. J. Climatol., 30, 1526-1537, https://doi.org/10.1002/joc.1999, 2010.

Federico, S., Bellecci, C., and Colacino, M.: Quantitative precipitation forecast of the Soverato flood: The role of orography and surface fluxes, Nuovo Cimento, 26, 7-22, 2003a.

Federico, S., Bellecci, C., and Colacino, M.: Numerical simulation oh Crotone flood: storm evolution, Nuovo Cimento, 26, 357-371, 2003 b.

Federico, S., Avolio, E., Bellecci, C., Lavagnini, A., and Walko, R. L.: Predictability of intense rain storms in the Central Mediterraneanbasin: sensitivity to upper-level forcing, Adv. Geosci., 12, 5-18, https://doi.org/10.5194/adgeo-12-5-2007, 2007.

Groisman, P. Y., Knight, R. W., Easterling, D. R., Karl, T. R., Hegerl, G. C., and Razuvaev, V. N.: Trends in intense precipitation in the climate record, J. Climate, 18, 1326-1350, https://doi.org/10.1175/JCLI3339.1, 2005.

Guan, Y., Zheng, F., Zhang, P., and Qin, C.: Spatial and temporal changes of meteorological disasters in China during 19502013, Nat. Hazards, 75, 2607, https://doi.org/10.1007/s11069014-1446-3, 2015.

Gullà, G., Caloiero, T., Coscarelli, R., and Petrucci, O.: A proposal for a methodological approach to the characterisation of Widespread Landslide Events: an application to Southern Italy, Nat. Hazards Earth Syst. Sci., 12, 165-173, https://doi.org/10.5194/nhess-12-165-2012, 2012.

Kjeldsen, T. R., Macdonald, N., Lang, M., Mediero, L., Albuquerque, T., Bogdanowicz, E., Brázdil, R., Castellarin, A.,
David, V., Fleig, A., Gül, G. O., Kriauciuniene, J., Kohnovám, S., Merz, B., Nicholson, O., Roald, L. A., Salinas, J. L., Sarauskiene, D., Šraj, M., Strupczewski, W., Szolgaym, J., Toumazis, A., Vanneuville, W., Veijalainen, N., and Wilson, D.: Documentary evidence of past floods in Europe and their utility in flood frequency estimation, J. Hydrol., 517, 963-973, https://doi.org/10.1016/j.jhydrol.2014.06.038, 2014.

Kunkel, K. E., Andsager, K., and Easterling, D. R.: Long-term trends in extreme precipitation events over the conterminous United States and Canada, J. Climate, 12, 2515-2527, https://doi.org/10.1175/15200442(1999)012<2515:LTTIEP>2.0.CO;2, 1999.

Min, S. K., Zhang, X., Zwiers, F. W., and Hegerl, G. C.: Human contribution to more-intense precipitation extremes, Nature, 470 , 378-381, https://doi.org/10.1038/nature09763, 2011.

Ogniben, L.: Schema geologico della Calabria in base ai dati odierni, Geol. Romana, 12, 243-585, 1973.

O'Gorman, P. A. and Schneiderb, T.: The physical basis for increases in precipitation extremes in simulations of 21st-century climate change, P. Natl. Acad. Sci. USA, 106, 14773-14777, https://doi.org/10.1073/pnas.0907610106, 2009.

Osborn, T. J., Hulme, M., Jones, P. D., and Basnett, T. A.: Observed trends in the daily intensity of United Kingdom precipitation, Int. J. Climatol., 20, 347-364, https://doi.org/10.1002/(SICI)10970088(20000330)20:4<347::AID-JOC475>3.0.CO;2-C, 2002.

Pall, P., Allen, M. R., and Stone, D. A.: Testing the Clausius-Clapeyron constraint on changes in extreme precipitation under $\mathrm{CO}_{2}$ warming, Clim. Dynam., 28, 351-363, https://doi.org/10.1007/s00382-006-0180-2, 2006.

Palmieri, W., Petrucci, O., and Versace, P.: La difesa del suolo nell'Ottocento nel Mezzogiorno d'Italia, IV Quaderno dell'Osservatorio di Documentazione Ambientale, Rubbettino, Soveria Mannelli (CZ), Italy, 184 pp., 2011 (in Italian).

Papathoma-Köhle, M., Zischg, A., Fuchs, S., Glade, T., and Keiler, M.: Loss estimation for landslides in mountain areas - An integrated toolbox for vulnerability assessment and damage documentation, Environ. Model. Softw., 63, 156-169, https://doi.org/10.1016/j.envsoft.2014.10.003, 2015.

Pasqua, A. A. and Petrucci, O.: Eventi alluvionali in Calabria nel decennio 1990-1999, CNR-IRPI, Rende (CS), Italy, 270 pp., 2016 (in Italian).

Petrucci, O. and Pasqua, A. A.: Damaging events along roads during bad weather periods: a case study in Calabria (Italy), Nat. Hazards Earth Syst. Sci., 12, 365-378, https://doi.org/10.5194/nhess12-365-2012, 2012.

Petrucci, O. and Pasqua, A. A.: Historical Climatology of Storm Events in the Mediterranean: A Case Study of Damaging Hydrological Events in Calabria, Southern Italy, in: Storminess and Environmental Change, Springer, the Netherlands, 2014.

Petrucci, O. and Polemio, M.: The role of meteorological and climatic conditions in the occurrence of damaging hydro-geologic events in Southern Italy, Nat. Hazards Earth Syst. Sci., 9, 105118, https://doi.org/10.5194/nhess-9-105-2009, 2009.

Petrucci, O. and Versace, P.: Frane e Alluvioni in Provincia di Cosenza Agli Inizi del "900: Ricerche Storiche nella Documentazione del Genio Civile. I Quaderno dell'Osservatorio di Documentazione Ambientale", Bios, Rende (CS), Italy, 2005 (in Italian). 
Petrucci, O. and Versace, P.: Frane e Alluvioni in Provincia di Cosenza tra il 1930 e il 1950: RicercheStoriche nella Documentazione del Genio Civile, in: II Quaderno dell'Osservatorio di Documentazione Ambientale, Bios, Rende (CS), Italy, 2007 (in Italian).

Petrucci, O., Pasqua, A. A., and Gullà, G.: Landslide damage assessment using the Support Analysis Framework (SAF): the 2009 landsliding event in Calabria (Italy), Adv. Geosci., 26, 1317, https://doi.org/10.5194/adgeo-26-13-2010, 2010.

Petrucci, O., Aceto, L., and Pasqua, A.: "PEOPLE”, Mendeley Data, v1, https://doi.org/10.17632/mz2b8f8ys7.1, 2017.

Plummer, N., Salinger, M. J., Nicholls, N., Ramasamy, S., Hennessy, K. J., Leighton, R. M., Trewin, B., Page, C. M., and Lough, J. M.: Changes in climate extremes over the Australian region and New Zealand during the twentieth century, Climatic Change, 42, 183-202, https://doi.org/10.1023/A:1005472418209, 1999.

Reiser, H. and Kutiel, H.: Rainfall uncertainty in the Mediterranean: time series, uncertainty, and extreme events, Theor. Appl. Climatol., 104, 357, https://doi.org/10.1007/s00704-010-0345-0, 2010.

Toreti, A., Xoplaki, E., Maraun, D., Kuglitsch, F. G., Wanner, H., and Luterbacher, J.: Characterisation of extreme winter precipitation in Mediterranean coastal sites and associated anomalous atmospheric circulation patterns, Nat. Hazards Earth Syst. Sci., 10, 1037-1050, https://doi.org/10.5194/nhess-10-1037-2010, 2010.

Toreti, A., Naveau, P., Zampieri, M., Schindler, A., Scoccimarro, E., Xoplaki, E., Dijkstra, H. A., Gualdi, S., and Luterbacher, J.: Projections of global changes in precipitation extremes from Coupled Model Intercomparison Project Phase 5 models, Geophys. Res. Lett., 40, 4887-4892, https://doi.org/10.1002/grl.50940, 2013.
Tortorici, L.: Analisi delle deformazioni fragili dei sedimenti postorogeni della Calabria settentrionale, B. Soc. Geol. Ital., 100, 291-308, 1982.

Villarini, G., Smith, J. A., Baeck, M. L., Vitolo, R., Stephenson, D. B., and Krajewski, W. F.: On the frequency of heavy rainfall for the Midwest of the United States, J. Hydrol., 400, 103-120, https://doi.org/10.1016/j.jhydrol.2011.01.027, 2011.

Wentz, F. J., Ricciardulli, L., Hilburn, K., and Mears, C.: How much more rain will global warming bring?, Science, 317, 233-235, https://doi.org/10.1126/science.1140746, 2007.

Westra, S., Alexander, L. V., and Zwiers, F. W.: Global Increasing Trends in Annual Maximum Daily Precipitation, J. Climate, 26, 3904-3918, https://doi.org/10.1175/JCLI-D-12-00502.1, 2013.

Zhang, X., Zwiers, F. W., Hegerl, G. C., Lambert, F. H., Gillett, N. P., Solomon, S., Stott, P. A., and Nozawa, T.: Detection of human influence on twentieth-century precipitation trends, Nature, 448, 461-465, https://doi.org/10.1038/nature06025, 2007. 